\title{
ON BYZANTINE THEME IN TAURICA DURING THE REIGN OF EMPEROR NIKEPHOROS I (802-811): CRITICAL COMMENTS ON THE HYPOTHESIS BY TIBOR ŽIVKOVIĆ
}

\author{
Valery E. Naumenko \\ Crimean Federal University, Simferopol, Russian Federation
}

\begin{abstract}
The article is devoted to the study of one of the debatable issues in the history of Taurica of the $9^{\text {th }}$ century - the time of formation of the Byzantine theme (Byzantine district) on the peninsula. The author analyzes the hypothesis of T. Zhivkovich on the possibility of establishing a theme in Taurica at the end of the reign of Emperor Nicephor I. It is not the originality that provokes interest, but the range of issues on the history of the region and the theme system in Byzantium, which also arise in the process of discussing the version of the Serbian historian. The most important of them include the author's attempt to abandon the identification of the Klimata theme in Tacticon and early Byzantine theme of Constantine Porphyrogenitus and Theophanes; secondly, the new date he proposed for the compilation of Tacticon of F.I. Uspensky (about 812-813). Finally, T. Zhivkovich's interpretation of the institution of archons in Cherson provokes criticism as an example of the long-term preservation of the collegiate body of municipal self-government.

Key words: Byzantium, theme, Archon, Klimata theme, Cherson theme, John Grammaticus.

Citation. Naumenko V.E. On Byzantine Theme in Taurica During the Reign of Emperor Nikephoros I (802-811): Critical Comments on the Hypothesis by Tibor Živković. Vestnik Volgogradskogo gosudarstvennogo universiteta. Seriya 4, Istoriya. Regionovedenie. Mezhdunarodnye otnosheniya [Science Journal of Volgograd State University. History. Area Studies. International Relations], 2017, vol. 22, no. 5, pp. $75-85$ (in Russian). DOI: https://doi.org/ 10.15688/jvolsu4.2017.5.7
\end{abstract}

\section{О ВИЗАНТИЙСКОЙ ФЕМЕ В ТАВРИКЕ В ПРАВЛЕНИЕ ИМПЕРАТОРА НИКИФОРА І ГЕНИКА (802-811): КРИТИЧЕСКИЕ ЗАМЕЧАНИЯ К ГИПОТЕЗЕ ТИБОРА ЖИВКОВИЧА}

\author{
Валерий Евгеньевич Науменко \\ Крымский федеральный университет им. В.И. Вернадского, г. Симферополь, Российская Федерация
}

\footnotetext{
Аннотация. Статья посвящена изучению одного из дискуссионных вопросов в истории Таврики IX в. - времени образования византийской фемы на полуострове. Анализируется гипотеза Т. Живковича о возможности учреждения фемы в Таврике в конце правления императора Никифора I. Интерес вызывает не столько ее оригинальность, сколько круг вопросов по истории региона и фемной системы в Византии, которые дополнительно возникают в процессе обсуждения версии сербского историка. К числу важнейших из них следует отнести, во-первых, попытку автора отказаться от отождествления фемы Климатов в Тактиконе Ф.И. Успенского и ранней византийской фемы у Константина Багрянородного и Продолжателя Феофана, во-вторых, предложенную им новую дату для составления Тактикона Ф.И. Успенского (около 812-813 гг.). Наконец, критику вызывает интерпретация Т. Живковича института архонтов в Херсоне как примера длительного сохранения коллегиального органа муниципального самоуправления.
}

Ключевые слова: Византия, фема, архонт, фема Климатов, фема Херсон, Иоанн Грамматик. 
Цитирование. Науменко В. Е. О византийской феме в Таврике в правление императора Никифора I Геника (802-811): критические замечания к гипотезе Тибора Живковича // Вестник Волгоградского государственного университета. Серия 4, История. Регионоведение. Международные отношения. - 2017. - Т. 22, № 5. - С. $75-$ 85. - DOI: https://doi.org/10.15688/jvolsu4.2017.5.7

Казалось бы, что вышедшая почти 20 лет назад на русском и английском языках статья К. Цукермана подвела итог под многолетней дискуссией вокруг даты учреждения первоначальной византийской фемы в Таврике - фемы Климатов. Французский исследователь, опираясь на новую хронологию вступления на патриарший престол Иоанна VII Грамматика (21 апреля 838 г.), установленную У. Тредголдом [51, p. 178-180], а также последовательность связанных между собой событий, предшествующих образованию фемы на полуострове, которые изложены в сочинениях Константина VII Багрянородного и Продолжателя Феофана [8, с. 170-173; 18, с. 5557], аргументированно предложил их новый хронологический ряд:

1. Интронизация Иоанна VII Грамматика: 21 апреля 838 г.

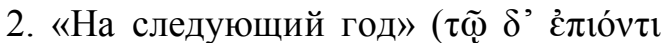

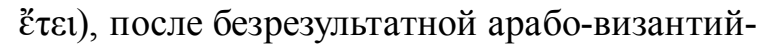
ской военной кампании весны-лета 839 г., прием в Константинополе императором Феофилом (829-842) хазарского посольства с просьбой построить крепость Саркел на Нижнем Дону: не ранее конияа лета 839 г.

3. Византийская экспедиция во главе с Петроной Каматиром и строительство Саркела: 840 г. и, возможно, зима 840-841 г2.

4. Возвращение Петроны в Константинополь, его доклад Феофилу об увиденном в Херсоне и в Хазарии и решение об организации фемы в Таврике: весна - лето 841 г. [25, с. $312-316 ; 54$, р. 210-215.].

В свое время мы полностью согласились с гипотезой У. Тредголда - К. Цукермана [10, c. 689-692]. Она была поддержана, пусть и с некоторыми коррективами, многими отечественными и зарубежными исследователями [1, с. $215-216 ; 34$, с. 291 ; 28 , с. 311 ; 46, с. 320 ; 39 , p. 169,$174 ; 19$, с. $222-223 ; 27$, с. $269 ; 29$, p. 33; 17, с. 115]. Однако, на сегодняшний день, эту поддержку трудно назвать повсеместной. В последние годы оба наиболее важных тезиса данной гипотезы (дата интронизации Иоанна VII Грамматика и ее хронологичес- кая связь с учреждением фемы в Таврике) вновь вошли в разряд дискуссионных.

Подавляющее большинство авторов, вышедших за последние 20-25 лет обобщающих либо справочно-энциклопедических работ по истории Византийской империи и восточно-христианской церкви при установлении даты интронизации Иоанна VII Грамматика по-прежнему следуют старой точке зрения В. Грюмеля (21 января 837 г.) [38, p. 162-166], при этом без особой аргументации и обсуждения версии У. Тредголда [50, р. 1052; 43, S. 176; 40, S. 326, № 3199; 32, p. 543, 570; 30, p. $290 ; 5$, с. 485$]$. Сравнительно недавно поставлена под сомнение сама возможность хронологической связи в источниках между вступлением на патриарший престол Иоанна Грамматика и датой учреждения фемы в Таврике. В результате, автор этой гипотезы, настаивая на невозможности использования сведений Продолжателя Феофана при реконструкции последовательности интересующих нас событий, вынужден был вновь вернуться к прежней (широкой) хронологии для учреждения византийской фемы на полуострове-между 833 и 842 гг., которая была основной в историографии на протяжении всего XX в. [15, c. 552-557].

Обзору перечисленных спорных вопросов, связанных с ранней историей фемы в Крыму, и анализу аргументов сторонников существующих точек зрений по этой проблематике посвящена наша отдельная работа [14]. Чтобы избежать повторов, заметим, что основной, на сегодняшний день, остается всетаки версия событий, предложенная впервые У. Тредголдом и К. Цукерманом. Также важно подчеркнуть, что, при всей разноголосице мнений, все участники дискуссии придерживаются позиции искать решение данной научной проблемы в пределах правления императора Феофила (829-842). Это прямо согласуется не только с информацией наших основных источников - Константина Багрянородного и Продолжателя Феофана, но и не противоречит единственному официальному визан- 
тийскому документу, упоминающему фему Климатов - Тактикону Ф.И. Успенского, составленному около 842-843 гг. [45, p. 45-47].

В этой связи более серьезного внимания заслуживает гипотеза Тибора Живковича, предложившего поместить интересующую нас реформу системы административного устройства византийских владений в Таврике в конце правления императора Никифора I Геника (802-811), что, насколько нам известно, в историографии было сделано впервые ([53, с. $52-$ 58, 81-85]; см. также более раннюю работу автора, где приводится традиционная, до появления работ К. Цукермана, дата образования фемы в Крыму - около 833 г.: [7, с. 347]). Интерес вызывает даже не столько ее новизна, сколько круг вопросов по истории региона и фемной системы в Византии в целом, которые дополнительно возникают в процессе обсуждения версии сербского историка, оставшейся практически не известной специалистам (исключение: [23, с. 116, 118-119]). В своей статье мы попытаемся дать критический анализ точки зрения Т. Живковича, наиболее оригинальной и одновременно наиболее искусственной гипотезы о времени появления фемы в Таврике в современной историографии. Ее слабости, как мы попытаемся показать, связаны с лакунами в источниковой и историографической базе исследования, что, тем не менее, не лишает работу научной ценности.

Свою гипотезу Т. Живкович сформулировал в статье, которая, по сути, является концептуальной попыткой представить обновленную картину политических и административных преобразований на северных и северозападных окраинах Византии в конце VIIIIX вв. [53, p. 84]. Работа содержит многочисленные ценные наблюдения, особенно в отношении ранней истории ряда балканских фем (Далмации, Стримона). Однако, нас в данном случае интересует только та часть исследования, которая посвящена хронологии событий, связанных с введением фемной системы в Таврике. Суммарно основные выводы автора выглядят следующим образом.

По мнению сербского историка, введение фемной системы в Таврике проходило в два этапа. На первом из них была учреждена фема Климатов, территория которой, с учетом содержание топонима «климаты» в трактатах Константина Багрянородного, охватывала области между Херсоном и Боспором. Сам Херсон, несмотря на географическую принадлежность области Климатов, не был включен в состав новой фемы, оставаясь под управлением архонтов, не зависимых от фемного стратига. Дату образования фемы Климатов, как и ряда других византийских фем - Диррахия, Халдии и Крита, Т. Живкович относит к концу правления Никифора I Геника. Результаты этой реформы впервые нашли отражение в Тактиконе Ф.И. Успенского, записанного, по его мнению, при преемнике Никифора I императоре Михаиле I Рангаве (811-813), в период между июнем 812 г., когда был заключен известный мир с франками, и июлем 813 г., когда Михаил I был отстранен от власти.

На втором этапе происходит реорганизация фемы Климатов в фему Херсон, означавшая переход города Херсон под прямое управление византийского стратига, превращение его в центр обширной провинции и отмену института городских архонтов. Как считает Т. Живкович, Константин Багрянородный, относивший появление стратига фемы в Херсоне ко времени императора Феофила, на самом деле не знал о точной дате этой реформы. Впрочем, и сам автор статьи колеблется при таком выборе. В целом, отдавая предпочтение традиционной хронологии (после 833834 гг.), он не исключает и более поздней датировки трансформации фемы Климатов в фему Херсон, вплоть до времени совместного правления императоров Василия I и Александра (869-879), когда выходят из употребления печати архонтов Херсона и появляются первые моливдовулы стратигов фемы Херсон [53, p. 52-58, 81-85].

Отдавая должное многочисленным оригинальным замечаниям автора, мы, тем не менее, вынуждены заключить, что проделанная им работа имеет множество слабых мест. Критику вызывает, как минимум, три важных позиции в статье.

Первое замечание касается тезиса Т. Живковича о необходимости рассматривать фему Климатов в Тактиконе Ф.И. Успенского и первоначальную фему в Херсоне Константина Багрянородного и Продолжателя Феофана как разновременные этапы политико-адми- 
нистративных преобразований Византии в Таврике в течение IX в. [45, p. 48-49; 8, с. 170173; 18, с. 56-57]. Последнюю он пытается идентифицировать с упоминаемой в официальных византийских источниках, начиная с Тактикона Филофея (около 899 г.), фемой Херсон [45, p. 100-101, 104-105] и, таким образом, отнести ее учреждение к более позднему, чем принято сейчас считать, времени (о современной дате трансформации фемы Климатов в фему Херсон - рубеж 40-50-х гг. или 50-е гг. IX в., см.: [4, с. $50 ; 13$, с. 484]).

Однако, Константин Багрянородный ясно свидетельствует о том, что император Феофил, впервые задумавший проект реформирования системы управления в византийской Таврике, изначально направляет стратига фемы в Херсон, «повелев тогдашнему протевону и всем [прочим] повиноваться ему. С той поры и до сего дня стало правилом избирать для Херсона стратигов из здешних» $[8$, с. $172-$ 173]. Эту фразу у него, безусловно, заимствует Продолжатель Феофана (см. об этом: [36, p. 10]). Из сказанного становится понятным то особое значение, которое придавалось Херсону в структуре новой военно-административной единицы с момента ее создания. Город сразу стал выполнять роль столичного центра и резиденции стратига фемы.

На этот же факт, бесспорно, указывают и материалы сфрагистики, связанные с историей фемы Климатов. В легендах трех сохранившихся печатей чиновников фемы содержится топоним «...Климатов Херсона» ([21, c. $149-150$, № $14 ; 49$, p. 54 , № $16 ; 3$, c. 126-127, 134, рис. 6, № 6]; все печати собраны в одном каталоге: [29, p. 118-119, № 26-27] (здесь же наблюдение о возможности изготовления их одной парой матриц, то есть принадлежности одному чиновнику в кратковременный период исполнения им своих обязанностей)). Это указывает на включение и особый (столичный) статус Херсона в составе нового военно-административного округа, территория которого охватывала, как известно, всю область Климатов на полуострове, то есть области горного и южнобережного Крыма, расположенные между Херсоном и Боспором [10, c. 692-698; иную трактовку содержания топонима «Климаты», ограничивающую его пределами горной части Крыма, см.: 25, с. 317
319]. Несмотря на немногочисленность этих моливдовулов, обратим все-таки внимание на географию находок - Херсонес (И.В. Соколова), Судак (Е.В. Степанова) и район горы Демерджи (Н.А. Алексеенко) на южном берегу полуострова, которая представляется не случайной и может свидетельствовать о зонах политических интересов и личной ответственности руководства византийской администрации в регионе в это время.

В этой связи особый интерес вызывает интерпретация печати чиновника фемы (?) с легендой «...пяти Климатов», опубликованной Н. Икономидесом и Дж. Несбиттом [33, p. 182, № 81.1]. Издатели совершенно справедливо локализуют место службы владельца моливдовула в феме Климатов в Таврике. В таком случае в нашем распоряжении появляется наилучший, на сегодняшний день, источник для анализа территориальной структуры фемы, совпадающей абсолютно точно с числом регионов (Херсон, Боспор, Готия, Фуллы, Сугдея), включенных к концу IX в. в систему церковно-административных округов (епархий) Константинопольского патриархата на полуострове (Речь идет об информации в нотиции патриарха Николая I Мистика, составленной между 901 и 907 гг.: [35, p. 273274]; о крымской части нотиции см.: [11, c. 142-144]).

Другое замечание к статье Т. Живковича связано с его попыткой предложить новую дату для Тактикона Ф.И. Успенского, где впервые фиксируется византийская фема в Таврике. Как уже говорилось, по мнению автора, тактикон был составлен в правление Михаила I Рангаве, между июнем 812 и июлем 813 гг., и, по сути, подвел итоги военно-административных преобразований императора Никифора I Геника с целью укрепления западных, южных и северных границ Византии. Результатом этих реформ является учреждение фем Фессалоника, Диррахий, Крит и Климаты в первые годы IX в., что подчеркивается их наличием в конце списка военно-административных округов империи этого времени в тактиконе [53, p. 84-85].

Нужно отметить, что это уже не первая попытка в историографии отказаться от традиционной датировки Тактикона Ф.И. Успенского временем совместного правления Ми- 
хаила III и императрицы Феодоры (см., прежде всего: [41, б. 497-503], где автор датировал тактикон периодом между 809 и 828 гг. и также выступал против отождествления фем Климатов и Херсон; критику этой гипотезы см.: $[16$, с. $40-48]$; классическую точку зрения на время составления Тактикона Ф.И. Успенского (между 842-856 гг.) см.: [31, p. 12-13]). Пожалуй, наибольший интерес представляет анализ Т. Живковича проблемы образования крупных балканских фем Византии в конце VIII - первой половине IX в., который приводит автора к закономерному выводу о том, что в этом процессе организации военно-административных пределов империи в регионе особую роль сыграло правление императора Никифора I (см. дискуссию вокруг хронологии образования фем Македония, Кефалония, Диррахий, Пелопоннес, Фессалоника: [45, p. 349-352; 37, p. 215-224; 48, б. 172-173, 178]; о правлении Никифора I см.: [52, p. 126-195]). Однако, из этого, на наш взгляд, совершенно не следует необходимость установления более ранней даты для тактикона.

В титуле источника однозначно упоминаются правящие особы (Михаил III и Феодора), в период пребывания у власти которых он был составлен [45, p. 46-47]. Замечание Т. Живковича о том, что эпитет «святая» по отношению к Феодоре мог быть использован только после ее канонизации, состоявшейся после смерти императрицы в 856 г., и соответственно эта вставка, скорее всего, являлась инициативой какого-то переписчика рукописи тактикона в XI-XIII вв. [53, p. 69-70], представляется нам слишком искусственной. Современная хронология Тактикона Ф.У. Успенского была предложена в свое время Н. Икономидесом - около 842-843 годов. Она обоснована упоминанием стратига Крита в конце перечня правителей византийских фем в это время [45, p. 45-47]. Остров, как известно, на короткое время был захвачен у арабов в начале правления Михаила III в ходе экспедиции во главе с патрикием и логофетом дрома Феоктистом, что и было зафиксировано составителями документа ([6, с. $154 ; 9$, с. 122-123], рассказ о походе Феоктиста на Крит см.: [18, c. 87,$296 ; 24$, c. 178$])$.

Наконец, еще одно критическое замечание касается характеристики Т. Живковичем содержания института архонтов в Херсоне в IX веке. По его мнению, в момент создания фемы Климатов архонты Херсона (во множественном числе, по автору) не были подчинены ее стратигу, что определенно свидетельствует о сохранении Херсоном прежних традиций местного городского самоуправления. Лишь исчезновение печатей архонтов к 7080-м гг. IX в. указывает на ликвидацию этого института и переход под непосредственное управление стратигом фемы Херсон одноименного города [53, p. 52, 55-56].

К сожалению, при написании статьи сербскому исследователю были не известны ряд важных публикаций, значительно расширивших бы уже к этому времени историографическую и источниковую базу для изучения института провинциального архонта в Херсоне (например: [46, p. 320; 28, с. 310316 ; 2 , с. 455-500]). Из-за этого его наблюдения оказались полностью зависимы от выводов И.В. Соколовой [20, с. 81-97; 47, p. 99-111], ныне утративших свою актуальность. Тем не менее, ввиду важности вопроса позволим себе, по крайней мере, в тезисной форме, высказаться в отношении современных представлений относительно вопросов хронологии и содержания данной институции в отдаленной византийской провинции.

Оба этих вопроса имеют разную степень изученности и соответственно дискуссионности в историографии. После публикации каталога византийских печатей из Херсона Н.А. Алексеенко, нет особых оснований сомневаться в существовании института византийского архонта в Херсоне на протяжении всего периода VIII - первой половины IX века. Его появление, очевидно, связано с перипетиями известных событий 710-711 гг. в истории города, подробно описанных Феофаном и Никифором $[26$, c. 64,164$]$. Ликвидация же должности архонта происходит вместе с трансформацией фемы Климатов в фему Херсон не позднее 850-х гг. На хронологию этих событий, в самом общем виде, указывают два фактических наблюдения. Архонты Херсона и стратиг фемы Климатов одновременно указаны среди должностных лиц империи еще в Тактиконе Ф.И. Успенского [45, p. 48-49, 56-57], наиболее же поздние моливдовулы городских архонтов датируются первой половиной - сере- 
диной IX в., что свидетельствует об исчезновении должности вместе с реорганизацией фемы Климатов в территориально более компактную фему Херсон [29, p. 17-28].

В то же время проблема содержания должности провинциального византийского архонта применительно к Херсону остается окончательно не решенной в историографии (об этом см. подробнее: [2, с. 469-487; 4, c. 439-441, 447-450]; о роли местных городских институтов в системе фемной администрации Херсона см. также: [23, с. 111-131; 42, p. 179-191]). Основную дискуссию вызывают вопросы ее коллегиальности либо единоличностного характера исполнение должности, а также степень полномочий архонта в системе управления городом.

На наш взгляд, следует согласиться с Н.А. Алексеенко в том, что в значительном собрании опубликованных ныне печатей херсонских архонтов (всего 128 экземпляров) каких-либо указаний на коллегиальность этой должности, по подобию муниципальной высшей магистратуры в позднеантичную эпоху, нет. Во всей коллекции имеется только восемь имен архонтов, управлявших городом не протяжении VIII - первой половины IX в., что свидетельствует в пользу единоличностного и длительного характера исполнения должности этого византийского функционера в регионе, назначаемого, вероятно, в Константинополе из числа представителей местной лояльной империи знати. Отдельные архонты могли выполнять свои обязанности на протяжении десяти и более лет, сменив при этом по несколько буллотириев [2, с. 475]. Следовательно, учитывая иконографический тип печатей архонтов и определенный разряд в византийском «табеле о рангах» (ипат, стратор, спафарий, спафарокандидат) их владельцев, длительность исполнения службы, естественным выглядит заключение о государственном, не муниципальном, характере этой должности в городе.

Пожалуй, главным аргументом сторонников сохранения коллегии архонтов в системе управления Херсона в период образования фемы является их упоминание в Тактиконе Ф.И. Успенского во множественном числе (в рукописи - oi $\alpha \rho \chi \sigma \tilde{\omega} v o \zeta$, реконструкция из-

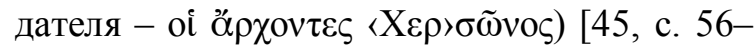

57]. Очевидная испорченность текста решается исследователями по-разному. Л. Маргетич предлагает видеть здесь lapsus переписчика и необходимость замены на «архонт Херсона» [44, с. 53]. Н.А. Алексеенко усматривает в записи пропуск некоторого объема текста и реконструирует ее как «оi ö $\rho \chi о \nu \tau \varepsilon \varsigma \tau \tilde{\omega} v$

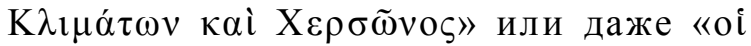

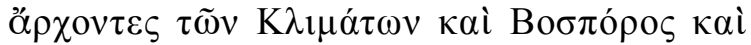

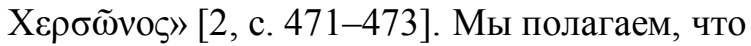
версия Л. Маргетича более вероятна. В этом случае напомним о недавно изданной печати Иоанна (?), императорского спафария и архонта Диррахия первой половины IX в. [22, с. 174]. Как известно в Тактиконе Ф.И. Успенского, наряду со стратигом Климатов и архонтами (?) Херсона, отмечены стратиг и архонты (во множественном числе) Диррахия [45, p. 48-49, 5657]. Опубликованная печать чиновника Диррахия, если она принадлежит городскому архонту, а не византийскому наместнику в одном из славянских округов, может окончательно разрешить эту дискуссию.

Однако, говоря о единоличностном характере должности архонта в Херсоне, излишним было бы видеть в нем византийского чиновника, наделенного всей полнотой военной и гражданской власти, как считает Н.А. Алексеенко [2, с. 475, 485-487; 4, с. 447]. В своей работе, посвященной эволюции византийских архонтатов на территории балканских провинций Византии, мы уже попытались показать, что причины появление такого рода административных округов в различных регионах империи, при всех нюансах в каждом конкретном случае, имеют и ряд общих модельных закономерностей. Во-первых, провинциальные архонтии появлялись, как правило, в отдаленных регионах империи, сложная политическая и этно-конфессиональная ситуация в которых не позволяла использовать традиционные для Византии принципы провинциального управления. Во-вторых, появление архонтата не означало ликвидацию местных органов управления, скорее, провинциальный архонт выполнял функции контроля за их действиями, что свидетельствует о значительной автономии такого рода административных округов. В-третьих, распространенной была практика назначения архонта лично императором или стратигом формирующейся фемы. Таким образом, 
сосуществование провинциальных архонтов и фемной администрации являлось обычным делом в системе территориального управления империи. Наконец, в-четвертых, сосуществование должностей стратигов фем и городских (окружных) архонтов ясно указывает на то, что последние являлись, прежде всего, гражданскими функционерами империи. Военные же обязанности возлагались на правителей фем. Именно эта практика становится определяющей для сохранения в налоговой системе Византийской империи $\mathrm{X}$ XI вв. термина «архонтия» для обозначения низшей фискальной территориальной единицы [12, с. 179-189].

Таким образом, проведенный анализ показывает общую слабую обоснованность гипотезы Т. Живковича в отношении ранней истории византийской фемы в Таврике, хотя она и содержит ряд оригинальных и ценных для дальнейших исследований наблюдений. Основной в данном случае остается версия событий, предложенная ранее У. Тредголдом и К. Цукерманом. По их мнению, первоначальная фема в Таврике (фема Климатов) появляется в конце правления императора Феофила, после интронизации патриарха Иоанна VII Грамматика (21 апреля 838 г.), вероятно, весной - летом 841 года. Более перспективным выглядит продолжение дискуссии в отношении обстоятельств образования фемы на северных границах Византийской империи в середине IX века. При этом внимание следует уделить не только анализу событий, происходивших в это время в Таврике и соседних регионах Северного Причерноморья, но и собственно их византийскому контексту. Объем современной источниковой базы, как нам представляется, позволяет это делать.

\section{СПИСОК СОКРАЩЕНИЙ}

$A Д C B$ - Античная древность и средние века. БИАС-Бахчисарайский историко-археологический сборник. Европы.

ДГВЕ - Древнейшие государства Восточной

ЗРВИ - Зборник Радова византолошког института.

МАИЭТ-Материалы по археологии, истории и этнографии Таврии.
ПЭ- Православная энциклопедия.

ТГЭ - Труды Государственного Эрмитажа.

$B M G S$ - Byzantine and Modern Greek Studies.

$D O P$ - Dumbarton Oaks Paper.

$O D B$ - Oxford Dictionary of Byzantium.

PmbZ-Prosopographie der mittelbyzantinischen Zeit.

$S B S$ - Studies in Byzantine Sigillography.

\section{СПИСОК ЛИТЕРАТУРЫ}

1. Айбабин, А. И. Этническая история ранневизантийского Крыма / А. И. Айбабин. - Симферополь : ДАР, 1999. - 352 с.

2. Алексеенко, Н. А. Архонтия Херсона VIIIIX вв. по данным сфрагистики / Н. А. Алексеннко // МАИЭТ. - 2002. - Вып. ІХ. - С. 455-500.

3. Алексеенко, Н. А. Новые находки византийских печатей на территории Крыма / Н. А. Алексеенко // АДСВ. - 2011. - Вып. 40. - С. 121-135.

4. Алексеенко, Н. А. Имперская администрация Херсона: от архонтии до катепаната (по данным сфрагистики) / Н. А. Алексеенко // ДГВЕ. 2014 год. Древняя Русь и средневековая Европа: возникновение государств / отв. ред. Т. Н. Джаксон. М. : Русский фонд содействия образованию и науке, 2016. - С. 435-474.

5. Афиногенов, Д. Е. Иоанн VII Грамматик / Д. Е. Афиногенов // ПЭ. - М. : Церковно-научный центр «Православная энциклопедия», 2015. - Т. 23. С. $485-486$.

6. Васильев, А. А. Византия и арабы. Ч. І. Политические отношения Византии и арабов за время Аморийской династии / А. А. Васильев. - СПб. : Тип. И. Н. Скороходова, 1900. - 210 с.

7. Живковић, Т. Јужни словени под византијском влашћу / Т. Живковић. - Београд : Историјски ин-т : Службени гласник, 2002. -514 с.

8. Константин Багрянородный. Об управлении империей / под ред. Г. Г. Литаврина, А. П. Новосельцева. - М. : Наука, 1991. - 496 с.

9. Мохов, А. С. Византийская армия в середине VIII - середине IX вв.: развитие военно-административных структур / А. С. Мохов. - Екатеринбург : Изд-во Уральского ун-та, 2013. - 278 с.

10. Науменко, В. Е. К вопросу о названии и дате учреждения византийской фемы в Таврике / В. Е. Науменко // МАИЭТ. - 1998. - Вып. VI. - С. 689-700.

11. Науменко, В. Е. К вопросу о церковно-административном устройстве Таврики в VIII-IX вв. (по данным Notitiae episcopatuum) / В. Е. Науменко // АДСВ. - 2003. - Вып. 34. - С. 123-145.

12. Науменко, В. Е. К вопросу о статусе славянских «архонтий» Македонии и Греции в «темные века» / В. Е. Науменко // Россия и мир: панорама исторического развития : сб. науч. ст., посвящ. 
70-летию ист. фак. Урал. гос. ун-та им. А. М. Горького. - Екатеринбург : Изд-во Урал. ун-та, 2008. C. $179-189$.

13. Науменко, В. Е. От фемы Климатов к феме Херсон: особенности византийской военно-административной модели в Таврике в середине IX начале Х в. / В. Е. Науменко // ДГВЕ. 2014 год. Древняя Русь и средневековая Европа: возникновение государств /отв. ред. Т. Н. Джаксон. - М. : Русский фонд содействия образованию и науке, 2016. C. 475-506.

14. Науменко, В. Е. О дате учреждения фемы Климатов в Таврике (продолжение дискуссии) / В. Е. Науменко // АДСВ. - Екатеринбург, 2017. Вып. 45 (в печати).

15. Никифоров, М. А. К дискуссии о дате учреждения византийской фемы в Таврике / М. А. Никифоров // МАИЭТ. - 2009. - Вып. ХV. - С. 550-557.

16. Острогорски, Г. Тактикон Успенског и тактикон Бенешевић. О времену њиховог постанка / Г. Острогорски // ЗРВИ. - 1953. - Књ. 2. - С. 39-57.

17. Петрухин, В. Я. Русь в IX-X веках. От призвания варягов до выбора веры / В. Я. Петрухин. М. : ФОРУМ : Неолит, 2013. - 464 с.

18. Продолжатель Феофана. Жизнеописания византийских царей / изд. подгот. Я. Н. Любарский. - СПб. : Наука, 1992. - 348 с.

19. Романчук, А. И. Исследования ХерсонесаХерсона : Раскопки. Гипотезы. Проблемы. Т. 2. Византийский город / А. И. Романчук. - Тюмень : Изд-во Тюмен. гос. ун-та, 2008. - 544 с.

20. Соколова, И. В. Печати архонтов Херсона / И. В. Соколова // ЗРВИ. - 1978. - Кн. 18. - С. 81-97.

21. Соколова, И. В. Монеты и печати византийского Херсона / И. В. Соколова. - Л. : Искусство, 1983. $-176 \mathrm{c}$.

22. Степанова, Е. В. Архонты Балкан VIII-X вв. (на примере печатей Государственного Эрмитажа) / Е. В. Степанова // ТГЭ. Т. 57. Балканский сборник. - СПб. : Изд-во Гос. Эрмитажа, 2011. C. $173-179$.

23. Храпунов, Н. И. К вопросу о роли городской общины в управлении византийским Херсоном в VIII-XI вв. / Н. И. Храпунов // АДСВ. - 2014. Вып. 42. - С. 111-131.

24. Хроника Симеона Магистра и Логофета / пер. А. Ю. Виноградова, ст. и коммент. П. В. Кузенкова. - М. : Русский фонд содействия образованию и науке, 2014. - 264 с.

25. Цукерман, К. К вопросу о ранней истории фемы Херсона / К. Цукерман // БИАС. - 1997. Вып. 1.-С. 312-323.

26. Чичуров, И. С. Византийские исторические сочинения: «Хронография» Феофана, «Бревиарий» Никифора / И. С. Чичуров. - М. : Наука, 1980. $216 \mathrm{c}$.
27. Чхаидзе, В. Н. Таматарха. Раннесредневековый город на Таманском полуострове / В. Н. Чхаидзе. - М. : ТАУС, 2008. - 328 с.

28. Шене, Ж.-К. Поздний архонт на примере Херсона / Ж.-К. Шене // МАИЭТ. - 2000. Вып. VII. -C. 310-317.

29. Alekseyenko, N. L'administration byzantine de Cherson. Cataloque des sceaux / N. Alekseyenko. Paris : ACHCByz, 2012.-268 p.

30. Auzepy, M.-F. State of Emergency/M.-F. Auzepy // The Cambridge History of the Byzantine Empire / ed. J. Shepard. - Cambridge : Cambridge Univ. Press, 2008. - P. 251-291.

31. Bury, J. B. The Imperial Administrative System in the Ninth Century. With a Revised Text of the Kletorologion of Philotheos / J. B. Bury. - London, HardPress Publishing, 2011. - 179 p.

32. Cambridge History of Christianity. Vol. 3. Early Medieval Christianities, c. 600 / ed. T. F. X. Noble, J. M. H. Smith. - Cambridge : Cambridge Univ. Press, 2008. - C. 1100 . -846 p.

33. Catalogue of byzantine seals at Dumbarton Oaks and in the Fogg Museum of Art. Vol. 1. Italy, North of the Balkans, North of the Balck Sea / ed. by J. Nesbitt, N. Oikonomides. - Washington : Dumbarton Oaks Research Libr. and Coll., 1991. - 244 p.

34. Dagron, G. Crimée ambiguë (IV-X siècles) / G Dagron // МАИЭТ. -2000. -Вып. VII. -C. 289-293.

35. Darrouzès, J. Notitiae Episcopatuum ecclesiae Constantinopolitanae / J. Darrouzès. - Paris : Inst. fr. d'études byzantines, 1981. $-522 \mathrm{p}$.

36. Chronographiae quae Theophanis Continuati Nomine Fertur. Lib. I-IV / eds. J. M. Featherstone, J. Signes-Codoňer. - Berlin : W. de Gruyter, 2015. $320 \mathrm{p}$.

37. Ferluga, J. Sur la date de la creation du theme de Dyrrachium / J. Ferluga // Byzantium on the Balkans. Studies on the Byzantine Administration and the Southern Slavs from the VII to the XII Centuries. Amsterdam : A. M. Hakkert, 1976. - P. 215-224.

38. Grumel, V. Chronologie des patriarches iconoclastes du IX s. / V. Grumel // Échos d'Orient. 1935. - T. 34. - P. 162-166.

39. Howard-Johnston, J. Byzantine Sources for Khazar History / J. Howard-Johnston // The World of the Khazars. New Perspectives. Selected Papers from the Jerusalem 1999 International Khazar Colloquium / ed. P. B. Golden, H. Ben-Shammai, A. Róna-Tas. Leiden; Boston : Brill, 2007. - P. 163-193.

40. Ioannes VII. Grammatikos // PmbZ. 2. Band: Georgios (\#2183) - Leon (\#4270). - Berlin ; New York : W. de Gruyter, 2000. - S. 326-331.

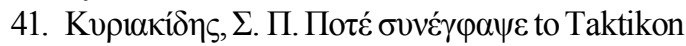

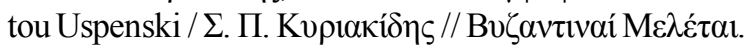

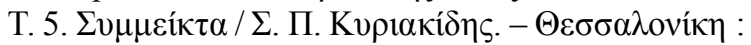
Kpóvos, 1939. - ¿. 497-503. 
42. Khrapunov, N. Continuity in the Administration of Byzantine Cherson According to Seals and Other Sources / N. Khrapunov // Byzantium and Rus' Seals / ed. by H. Ivakin, N. Khrapunov, W. Seibt. - Kyiv : Sheremetiev's Museum, 2015. - P. 179-191.

43. Lilie, R.-J. Ioannes VII. (837-843)/ R.-J. Lilie// Die Patriarchen der ikonoklastischen Zeit: Germanos I. - Methodius I. (715-847) / R.-J. Lilie (Hrsg.). - Frankfurt um Main ; New York : Peter Lang, 1999. - S. 169-182.

44. Margetić, L. «Provincijalni arhonti» Taktikona Uspenskog (s osobitim obzirom na arhonta Dalmacije) / L. Margetić // ЗРВИ. - 1991. - Књ. XXIX-XXX. C. $45-58$.

45. Oikonomidès, N. Les listes de préséance byzantines des IX et X siècles / N. Oikonomidès. Paris : Éd. du Centre National de la Recherche Scientifique, 1972. - $404 \mathrm{p}$.

46. Oikonomidès, N. Le «système» administratif byzantin en Crimée IX-X s. / N. Oikonomidès // МАИЭТ. - 2000. - Вып. VII. - C. 318-323.

47. Sokolova, I. V. Les sceaux byzantins de Cherson / I. V. Sokolova // SBS. Vol. 3. - Washington : Dumbarton Oaks Research Libr. and Coll., 1993. P. 99-111.

48. Stavridou-Zafraka, A. Slav Invasions and the Theme Organization in theBalkan peninsula/A. StavridouZafraka// BYZANTIAKA. - 1992. - T. 12. $-\Sigma$. 166-179.

49. Stepanova, E. New Seals from Sudak / E. Stepanova // SBS. Vol. 6. - Washington : Dumbarton Oaks Research Libr. and Coll., 1999. P. 47-58.

50. Talbot, A.-M. John VII Grammatikos / A.-M. Talbot, A. Cutler // ODB. Vol. II. - Oxford : Oxford Univ. Press, 1991. - P. 1052.

51. Treadgold, W. T. The Chronological Accuracy of the Chronicle of Symeon the Logothete for the Years 813-845 / W. T. Treadgold // DOP. - 1979. - Vol. 33. P. 157-197.

52. Treadgold, W. The Byzantine Revival, 780842 / W. Treadgold. - Stanford : Stanford Univ. Press, 1988. $-504 \mathrm{p}$.

53. Živković, T. Uspenskij's Taktikon and the thema of Dalmatia / T. Živković // BYZANTINA ¿YMMEIKTA. - 2005. - Vol. 17. - P. 49-85.

54. Zuckerman, C. Two notes on the early history of the thema of Cherson / C. Zuckerman // BMGS. 1997. - Vol. 21. - P. 210-222.

\section{REFERENCES}

1. Aibabin A.I. Etnicheskaya istoriya rannevizantiyskogo Kryma [Ethnic History of the Early Byzantine Crimea]. Simferopol, DAR Publ., 1999. $352 \mathrm{p}$.
2. Alekseenko N.A. Arkhontiya Khersona VIIIIX vv. po dannym sfragistiki [Archons of Cherson of the $8^{\text {th }}-9^{\text {th }}$ Centuries by Sphragistics Data]. MAIET, 2002, vol. IX, pp. 455-500.

3. Alekseenko N.A. Novye nakhodki vizantiyskikh pechatey na territorii Kryma [New Finds of Byzantine Seals on the Territory of the Crimea]. ADSV, 2011, vol. 40, pp. 121-135.

4. Alekseenko N.A. Imperskaya administratsiya Khersona: ot arkhontii do katepanata (po dannym sfragistiki) [Imperial Administration of Cherson: from the Archontery to the Katepanate (Sphragistic Data)]. Dzhakson T.N., ed. DGVE. 2014 god: Drevnyaya Rus i srednevekovaya Evropa: vozniknovenie gosudarstv [DGBE. 2014: Ancient Rus and Medieval Europe: the Emergence of States]. Moscow, Russkiy fond sodeystviya obrazovaniya i nauki, 2016, pp. 435-474.

5. Afinogenov D.E. Ioann VII Grammatik [John VII Grammaticus]. PE. Moscow, Tserkovno-nauchnyy tsentr «Pravoslavnaya entsiklopediya», 2015, vol. 23, pp. 485-486.

6. Vasilyev A.A. Vizantiya $i$ araby. Ch. I. Politicheskie otnosheniya Vizantii $i$ arabov za vremya Amoriyskoy dinastii [Byzantium and the Arabs. Part I. Political Relations of Byzantium and the Arabs during the Time of Amorian Dynasty]. Saint Petersburg, Tip. I.N. Skorokhodova, 1900. 210 p.

7. Zhivkovih T. Juzhni sloveni pod vizantijskom vlashжu. Beograd, Istorijski in-t; Sluzhbeni glasnik, 2002. 514 p.

8. Litavrin G.G., Novoseltsev A.P., eds. Konstantin Bagryanorodnyy. Ob upravlenii imperiey [Constantine Porphyrogenitus. On the Management of Empire]. Moscow, Nauka Publ., 1991. 496 p.

9. Mokhov A.S. Vizantiyskaya armiya $v$ seredine VIII - seredine IX vv.: razvitie voennoadministrativnykh struktur [Byzantine Army in the middle of the $8^{\text {th }}-$ mid $9^{\text {th }}$ Centuries: Development of Military-Administrative Structures]. Ekaterinburg, Izd-vo Uralskogo un-ta, 2013. $278 \mathrm{p}$.

10. Naumenko V.E. K voprosu o nazvanii i date uchrezhdeniya vizantiyskoy femy $\mathrm{v}$ Tavrike [On the Name and Date of the Establishment of Byzantine Theme in Taurica]. MAIET, 1998, vol. VI, pp. 689-700.

11. Naumenko V.E. K voprosu o tserkovnoadministrativnom ustroystve Tavriki v VIII-IX vv. (po dannym Notitiae episcopatuum) [On the Church and Administrative Apparatus of Taurika in the $8^{\text {th }}-9^{\text {th }}$ Centuries (by the Data of Notitiae episcopatuum)]. $A D S V, 2003$, vol. 34, pp. 123-145.

12. Naumenko V.E. K voprosu o statuse slavyanskikh «arkhontiy» Makedonii i Gretsii v «temnye veka» [On the Status of the Slavonic "Archons" of Macedonia and Greece in the "Dark Ages"]. Rossiya $i$ mir: panorama istoricheskogo razvitiya. Sbornik nauchnykh statey, posvyashchennyy 70-letiyu 
istoricheskogo fakulteta Uralskogo gosudarstvennogo universiteta im. A.M. Gorkogo [Russia and the World: a Panorama of Historical Development. A Collection of Scientific Articles Dedicated to the $70^{\text {th }}$ Anniversary of the Faculty of History of the Urals State University named after A.M. Gorky]. Ekaterinburg, Izd-vo Uralskogo un-ta, 2008, pp. 179-189.

13. Naumenko V.E. Ot femy Klimatov k feme Kherson: osobennosti vizantiyskoy voennoadministrativnoy modeli $\mathrm{v}$ Tavrike $\mathrm{v}$ seredine IX nachale X vv. [From the Klimata Theme to the Cherson Theme: Features of the Byzantine MilitaryAdministrative Model in Taurica in the Middle of the $9^{\text {th }}-$ Beginning of the $10^{\text {th }}$ Centuries]. Dzhakson T.N., ed. DGVE. 2014 god: Drevnyaya Rus $i$ srednevekovaya Evropa: vozniknovenie gosudarstv [DGBE. 2014: Ancient Rus and Medieval Europe: the Emergence of States]. Moscow, Russkiy fond sodeystviya obrazovaniya i nauki, 2016, pp. 475-506.

14. Naumenko V.E. O date uchrezhdeniya femy Klimatov v Tavrike (prodolzhenie diskussii) [On the Date of Establishment of the Klimata Theme in Taurica (Further Discussion)]. ADSV. Ekaterinburg, 2017, vol. 45 (in print).

15. Nikiforov M.A. K diskussii o date uchrezhdeniya vizantiyskoy femy v Tavrike [Discussion of the Date of Establishment of the Byzantine Theme in Taurica]. MAIET, 2009, vol. XV, pp. 550-557.

16. Ostrogorski G. Taktikon Uspenskog i taktikon Beneshevih. O vremenu njihovog postanka. ZRVI, 1953, vol. 2, pp. 39-57.

17. Petrukhin V.Ya. Rus v IX-X vekakh. Ot prizvaniya varyagov do vybora very [Russia in the $9^{\text {th }}-10^{\text {th }}$ Centuries. From the Varangians' Vocation to the Choice of Faith]. Moscow, FORUM Publ.; Neolit Publ., 2013. 464 p.

18. Lyubarskiy Ya.N., ed. Prodolzhatel Feofana. Zhizneopisaniya vizantiyskikh tsarey [The Successor of Theophanes. Biographies of Byzantine Kings]. Saint Petersburg, Nauka Publ., 1992. 348 p.

19. Romanchuk A.I. Issledovaniya KhersonesaKhersona. Raskopki. Gipotezy. Problemy. T. 2. Vizantiyskiy gorod [Research of Chersonesus Cherson. Excavations. Hypotheses. Problems. Vol. 2. Byzantine City]. Tyumen, Izd-vo Tyumenskogo gos. un-ta, 2008. 544 p.

20. Sokolova I.V. Pechati arkhontov Khersona [Seals of Archons of Cherson]. ZRVI, 1978, book 18, pp. 81-97.

21. Sokolova I.V. Monety i pechati vizantiyskogo Khersona [Coins and Seals of the Byzantine Cherson]. Leningrad, Iskusstvo Publ., 1983. 176 p.

22. Stepanova E.V. Arkhonty Balkan VIII-X vv. (na primere pechatey Gosudarstvennogo Ermitazha) [Archons of the Balkans in the $8^{\text {th }}-10^{\text {th }}$ Centuries (Example of the State Hermitage Seals)]. TGE. T. 57.
Balkanskiy sbornik. Saint Petersburg, Izd-vo Gos. Ermitazha, 2011, pp. 173-179.

23. Khrapunov N.I. K voprosu o roli gorodskoy obshchiny $\mathrm{v}$ upravlenii vizantiyskim Khersonom $\mathrm{v}$ VIII-XI vv. [On the Role of Urban Community in the Management of Byzantine Cherson in the $8^{\text {th }}-$ $11^{\text {th }}$ Centuries]. ADSV, 2014, vol. 42, pp. 111-131.

24. Vinogradov A.Yu., ed. Khronika Simeona Magistra i Logofeta [Chronicle of Simeon Magister and Logofet]. Moscow, Russkiy fond sodeystviya obrazovaniya i nauki, 2014. 264 p.

25. Tsukerman $\mathrm{K}$. K voprosu o ranney istorii femy Khersona [On the Early History of the Theme of Cherson]. BIAS, 1997, vol. 1, pp. 312-323.

26. Chichurov I.S. Vizantiyskie istoricheskie sochineniya: "Khronografiya» Feofana, «Breviariy» Nikifora [Byzantine Historical Works: The Chronography of Theophanes, The Breviary of Nicephorus]. Moscow, Nauka Publ., 1980. 216 p.

27. Chkhaidze V.N. Tamatarkha. Rannesrednevekovyy gorod na Tamanskom poluostrove [Tamatarha. Early Medieval Town on the Taman Peninsula]. Moscow, TAUS Publ., 2008. 328 p.

28. Shene Z.-K. Pozdniy arkhont na primere Khersona [The Late Archon as in the Case of Cherson]. MAIET, 2000, vol. VII, pp. 310-317.

29. Alekseyenko N. L'administration byzantine de Cherson. Cataloque des sceaux. Paris, ACHCByz, 2012. $268 \mathrm{p}$.

30. Auzepy M.-F. State of Emergency. Shepard J., ed. The Cambridge History of the Byzantine Empire. Cambridge, Cambridge Univ. Press, 2008, pp. 251-291.

31. Bury J.B. The Imperial Administrative System in the Ninth Century. With a Revised Text of the Kletorologion of Philotheos. London, HardPress Publishing, 2011. 179 p.

32. Smith J.M.H., Noble T.F.X., eds. Cambridge History of Christianity. Vol. 3. Early Medieval Christianities, c. 600. Cambridge, Cambridge Univ. Press, 2008, C. 1100.846 p.

33. Nesbitt J., Oikonomides N., eds. Catalogue of byzantine seals at Dumbarton Oaks and in the Fogg Museum of Art. Vol. 1: Italy, North of the Balkans, North of the Balck Sea. Washington, Dumbarton Oaks Research Libr. and Coll., 1991. 244 p.

34. Dagron G. Crimée ambiguë (IV-X siècles). MAIET, 2000 , vol. VII, pp. 289-293.

35. Darrouzès J. Notitiae Episcopatuum ecclesiae Constantinopolitanae. Paris, Inst. fr. d'études byzantines, 1981. $522 \mathrm{p}$.

36. Featherstone J.M., Signes-Codoňer J, eds. Chronographiae quae Theophanis Continuati Nomine Fertur. Lib. I-IV. Berlin, W. de Gruyter, 2015. 320 p.

37. Ferluga J. Sur la date de la creation du theme de Dyrrachium. Byzantium on the Balkans. Studies on the Byzantine Administration and the Southern 
Slavs from the VII to the XII Centuries. Amsterdam, A.M. Hakkert, 1976, pp. 215-224.

38. Grumel V. Chronologie des patriarches iconoclastes du IX s. Échos d'Orient, 1935, vol. 34, pp. 162-166.

39. Howard-Johnston J. Byzantine Sources for Khazar History. Golden P.B., Ben-Shammai H., RynaTas A., eds. The World of the Khazars. New Perspectives. Selected Papers from the Jerusalem 1999 International Khazar Colloquium. Leiden; Boston, Brill, 2007, pp. 163-193.

40. Ioannes VII. Grammatikos. PmbZ. 2. Band: Georgios (\#2183) - Leon (\#4270). Berlin; New York, W. de Gruyter, 2000, S. 326-331.

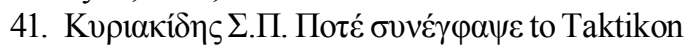

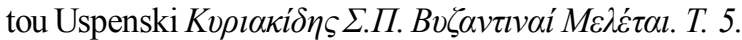

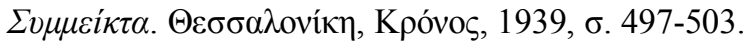

42. Khrapunov N. Continuity in the Administration of Byzantine Cherson according to Seals and Other Sources. Ivakin H., Khrapunov N., Seibt W., ed. Byzantium and Rus' Seals. Kyiv, Sheremetiev's Museum, 2015, pp. 179-191.

43. Lilie R.-J. Ioannes VII. (837-843). Lilie R.-J., ed. Die Patriarchen der ikonoklastischen Zeit: Germanos I. - Methodius I. (715-847). Frankfurt um Main; New York, Peter Lang, 1999, pp. 169-182.

44. Margetić L. «Provincijalni arhonti» Taktikona Uspenskog (s osobitim obzirom na arhonta Dalmacije). ZRVI, 1991, knj. XXIX-XXX, pp. 45-58.
45. Oikonomidès N. Les listes de préséance byzantines des IX et X siècles. Paris, Éd. du Centre National de la Recherche Scientifique, 1972. 404 p.

46. Oikonomidès N. Le «système» administratif byzantin en Crimée IX-X s. MAIET, 2000, vol. VII, pp. 318-323.

47. Sokolova I.V. Les sceaux byzantins de Cherson. SBS. Vol. 3. Washington, Dumbarton Oaks Research Libr. and Coll., 1993, pp. 99-111.

48. Stavridou-Zafraka A. Slav Invasions and the Theme Organization in the Balkan peninsula. $B Y Z A N T I A K A, 1992$, vol. 12, pp. 166-179.

49. Stepanova E. New Seals from Sudak. $S B S$. Vol. 6. Washington, Dumbarton Oaks Research Libr. and Coll., 1999, pp. 47-58.

50. Talbot A.-M., Cutler A. John VII Grammatikos. ODB. Vol. II. Oxford, Oxford Univ. Press, 1991. 1052 p.

51. Treadgold W.T. The Chronological Accuracy of the Chronicle of Symeon the Logothete for the Years 813-845. DOP, 1979, vol. 33, pp. 157-197.

52. Treadgold W. The Byzantine Revival, 780842. Stanford, Stanford Univ. Press, 1988. 504 p.

53. Živković T. Uspenskij's Taktikon and the thema of Dalmatia. BYZANTINA IYMMEIKTA, 2005, vol.17, pp. 49-85.

54. Zuckerman C. Two notes on the early history of the thema of Cherson. BMGS, 1997, vol. 21, pp. 210-222.

\section{Information about the Author}

Valeriy E. Naumenko, Candidate of Sciences (History), Associate Professor, Department of Ancient and Medieval History, Taurica Academy, Crimean Federal University, Prosp. Vernadsky, 20, 295007 Simferopol, Russian Federation, byzance@rambler.ru, https://orcid.org/0000-0002-2590-6314

\section{Информация об авторе}

Валерий Евгеньевич Науменко, кандидат исторических наук, доцент кафедры истории древнего мира и средних веков, Таврическая академия (структурное подразделение), Крымский федеральный университет им. В.И. Вернадского, просп. Вернадского, 20, 295007 г. Симферополь, Российская Федерация, byzance@rambler.ru, https://orcid.org/0000-0002-2590-6314 